\title{
Precariousness among Young People and Student Population in the Czech Republic
}

\author{
Andreja Sršen \\ Department of Sociology, University of Zagreb, Centre for Croatian Studies-Croatia \\ Email: asrsen@hrstud.hr
}

\section{Selma Muhič Dizdarevič}

Department of Civil Society Studies, Charles University in Prague, Faculty of Humanities. The Czech Republic Email: selma.muhic@fhs.cuni.cz

\section{Doi:10.5901/mjss.2014.v5n21p161}

\section{Abstract}

Over the last decade there has been increasing awareness of the persistence of atypical or non-standard forms of work. Precarity is a part of neoliberal globalization, involving greater capital mobility, the search for flexibility and lower costs. All industrial countries are faced with the basic problem of balancing security due to precarity. This article analyses the economic significance, causes and effects of precarious work among young people and students 'population of the Charles University, Faculty of Humanities in Prague and the extent to which it contributes to the flexibility of the labor market1. There is no precise definition of this concept in the Czech Republic on a statistical, legal or economic basis. Moreover there is no clear distinction between precarious employment and other non-standard work forms. Nevertheless, we argue that its definition is defined as forms of work for remuneration characterized by limited social benefits of the national welfare system. This research is carried out to find out what sort of paid work is undertaken by students during their studies, and to what extent it could be described as 'precarious'.

Keyword: precarious, the Czech Republic, students, economic significance, the labor market.

\section{Introduction}

Characteristics of precarious work such income and employment insecurity limit long-term planning especially among the young. Many are in highly uncertain work situations at ages when they traditionally would be considering starting a family. Young workers very often accept bad working conditions and salaries on a subsistence level. Many of them do not even have work contracts, placing them beyond the reach of social security systems. Consequently, the population under 25 runs the risk of falling into poverty and social exclusion in the EU countries. At the same time, according to the flexibility ideology, they need to ensure their "employability" and have to constantly develop new skills. It is obvious in this context that privileges of the young from "higher classes" lead to the fortification of the class divide. Hardest hit by social exclusion are the young people from the lower classes. Although there are individual differences in perceptions of insecurity and risk, people in general are increasingly worried about losing their jobs. We argue that in a precarious world, education is more essential than ever, as workers must constantly learn new work skills. There are conceptual problems with part-time work, probably the most widespread "atypical" form of work. Such work frequently lacks adequate social protection.

\section{Youth Unemployment - Reasons and Consequences}

Since the beginning of the economic and financial crisis in 2008, the number of young people in employment across the European Union has declined considerably. The main aim of the so-called Bologna Process is the development of the European Higher Education Area (EHEA) and the related sub-objectives (Balogh, 2011: 28). These are: an easily understandable and comparable education system, a cascading training cycle, the setting up of a credit system, support for mobility, European cooperation in quality assurance and support for the European dimension of Higher Education

\footnotetext{
1 This publication was supported by The Ministry of Education, Youth and Sports - Institutional Support for Long-term Development of Research Organizations - Charles University, Faculty of Humanities ( Charles University, Faculty of Humanities, 2012).
} 
(HE) (Szolár 2009, Polónyi 2010). Nowadays, young people during their studies and after finishing it face a particularly difficult time as a consequence of the financial crisis of 2008 and the subsequent fiscal challenges facing countries around the EU. The use of temporary employment contracts for young people had been on the rise in most countries before the recession began in late 2008, reflecting the desire of employers to adjust their workforces more easily as market conditions changed (The European Commission, 2013). At present, nearly 6 million people in Europe under the age of 25 are unemployed and a total of 7.5 million are not in employment, education or training. Youth unemployment rates in Europe stood at $23.5 \%$ in the first quarter of 2013, more than twice the - already very high - rate for the population at large (Ibidem). According to this statistic in some countries, more than half of the young people who want to work are unemployed. Across the EU, young people are far more likely than other groups to be struggling to find work, and when they do, the work is more likely to be precarious. Working students and apprentices are approximately $0.7 \%$ of all working citizens in the Czech Republic and about $4 \%$ of all students and apprentices' works. ${ }^{2}$ In 2012, the EU labour market was still being determined by the economic crisis. Key figures for the EU did not improve: they either continued to show negative trends (unemployment) or remained relatively stable in relation to the year before (employment).

See figure 1 (Teichgraber, 2012):

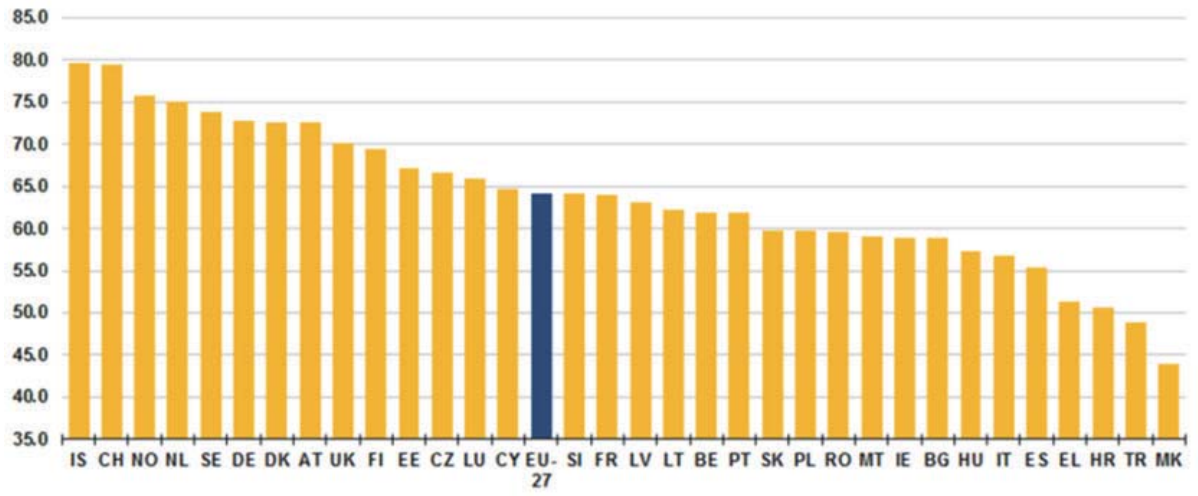

Figure 1: Employment rate of persons aged 15-64 years, 2012 - Source: Eurostat http://epp.eurostat.ec.europa.eu Istatistics_explained/index.php/Labour_market_and_labour_force_statistics\#cite_note-0

In addition, developments in the labour market did not affect Member States in the same way or to the same extent (Teichgraber, 2012). As a result, the differences between Member States increased. Increasingly in Europe and the Czech Republic stand out unilateral negative pressure on the flexibility of the labor market, reflected particularly in social dumping and still more onerous problem of so-called working poor, whose essence is unacceptable reduction in labor costs (in particular by reducing wages and reducing social security contributions), the deterioration of working conditions and the reduction of minimum labor standards and labor protection (Leschke, 2012; Martin 2009; Hammer, 2002; Janíčko, 2013: 498).

In 2012 EU employment rate for persons of working age (15-64) dropped slightly to $64.2 \%$ (-0.1 pps compared with 2011). For men, it fell to $69.8 \%$ (-0.3 pps), while for women it rose marginally to $58.6 \%$ (+0.1 pps) (see Table 1).

\footnotetext{
2 The source of information is the 2011 Census in the Czech Republic. See: http://www.czso.cz/eng/redakce.nsf/i/population
} 


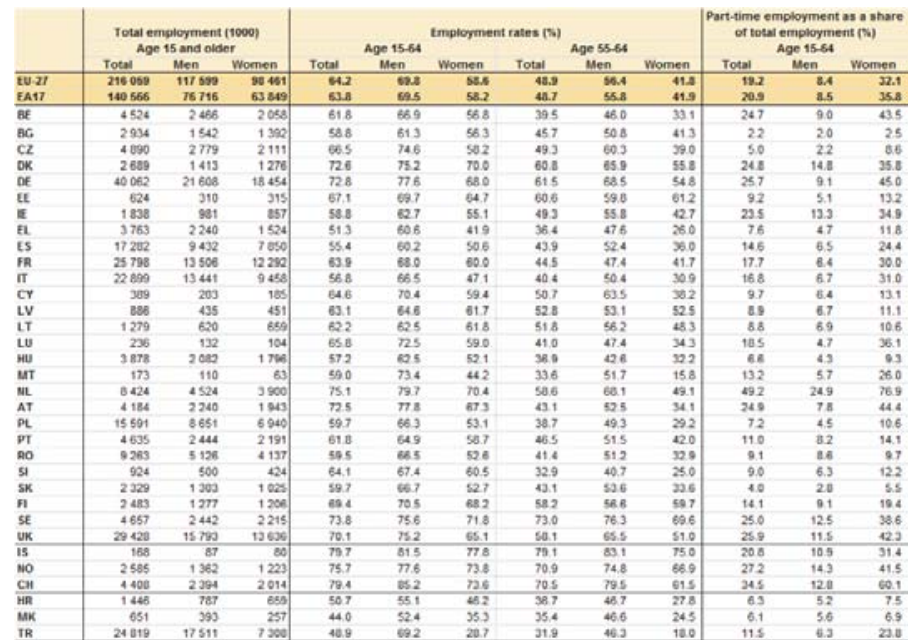

Table 1: Employed person's number, employment rates and share of part-time employment, by sex, 2012. Employed persons aged 15 years and older: composition by economic activity (main job), 2012. Source: European Union Labour force survey - annual results (Teichgraber 2012). (http://epp.eurostat.ec.europa.eu/statistics_explained/index.php/ Labour_market_and_labour_force_statistics\#cite_note-0).

Consequently, age appears to play a part in precarious employment status at the time of entry into working life (this may well be precariousness of a temporary type linked to probationary periods), but it also appears to play a part in precariousness for workers (aged over 54) who, on the eve of their retirement, are recruited into a new job. These figures mirror the unemployment figures which are particularly high for these two extreme age groups. Young people in the Czech Republic face a number of challenges in making the transition from education and training to the labour market. They also show higher rates of unemployment than older generations and often find themselves in a vulnerable position on the labour market. The category of "contract worker" includes workers with temporary contracts, in triangular relationships (those hired through agencies and subcontractors), and workers who are labelled as self-employed when they are in fact dependent on or integrated into the firm for which they perform the work. The literature presents specific groups as more likely to be working in precarious conditions, and the most frequently mentioned are young workers, mostly students

(Kretsos, 2010). Students on temporary contracts of various durations, be they directly employed or hired through an agency, may benefit from a job in the short term, but live with uncertainty as to whether their contract will be extended. Temporary contracts often also provide a lower wage, and do not always confer the same benefits, which often accrue with time and are directly linked to the status of the employment relationship. The result is a condition in which students cannot plan for their future, and lack the security of certain forms of social protection.

\section{The Characteristics of the Sample and the Basic Information of the Survey}

This article deals with the results of the online survey carried out within the project attracted 619 respondents from the Czech Republic, with more female than male respondents. ${ }^{3}$ Majority was in the age group 18 up to 24 . Within the project 6 interviews with the respondents were conducted and the respondents have been chosen randomly out of those who agreed in the survey to be interviewed. We have asked students who have completed at least one year of tertiary (higher) education and who have done paid work during their studies to complete it. We have carried out this survey in order to understand better what sort of work students do, and why, and the extent of precarious work among students. The article deals also with the economic significance, causes and effects of precarious work. Most of working students are university

\footnotetext{
${ }^{3}$ The survey is a part of a wider survey Study on Precarious work and social rights where the partner was Charles University, Faculty of Humanities. (see: McK McKay Sonia, Jefferys Steve, Paraksevopoulou Anna and Keles Janoj (2012) Study on Precarious work and social rights. Carried out for the European Commission. (VT/2010/084). Working Lives Research Institute, Faculty of Social Sciences and Humanities, London Metropolitan University. Available at: ec.europa.eu/social/BlobServlet?docld=7925\&langld=en
} 
students with wide variety of occupations. Most respondents work regularly during their term time, followed by those who work occasionally during the term time. Vast majority of the respondents had a job during 12 month preceding our survey. In our survey almost all students were born in the Czech Republic, very small majority was from the EU and EEA countries, while only 3 respondents were from the third-country national countries. This fact is reflected also in their citizenship, which is in almost all cases Czech. What is especially interesting is that vast majority of the respondents' claims their work is not related to their future job.

\section{Theoretical Background of the Nature of Precarious Work}

There is no nationally (or indeed European) accepted definition of precariousness (McKay et al 2012). The literature suggests that it is not just the nature of work that makes it precarious, but it is also the conditions under which work is performed. One of the challenges identified in the literature is the great diversity in both labour conditions and social security, and protection within Europe, and moreover the erosion of previously existing rights (Cremers, 2010). The concept of precariousness, generally speaking, involves instability, lack of protection, insecurity and social or economic vulnerability (Kalleberg, 2009). Over the past years, economic crises in the EU members and turbulences on the financial markets have led to wide spread anxiety among students. The normalization of precarious work among students is already showing its deeply damaging impacts on studying at large. From the social point of view we could say that the most upsetting element of precarious work is its influence on societies. A high proportion of precarious work in a community seems to coincide with a lower than average level of neighborhood cooperation and cohesion, and a disproportionate decline in group memberships and associations among poorer communities (Stone, 2000). A study on Europe found that "the number of young workers with temporary contracts or who are employed through temporary agencies has increased along with the overall use of such flexible contracts. In some Member States - the Czech Republic, Hungary, Ireland, Latvia and Luxembourg - the proportion of young workers on temporary contracts (out of the entire young labour force) rose by more than 6 per cent between the third quarter of 2008 and the third quarter of 2010" (Eurostat Labour Force Survey, 2010). ${ }^{4}$ The precarious nature of these contracts also leaves young people excluded from benefits systems. The risk of losing financial independence and having to rely on lower social welfare payouts can lead to further social exclusion. ${ }^{5}$ It is not surprising therefore that youth are also more likely to fear losing their jobs (Ibidem). We argue that that there is a connection between the social class background of the students and their propensity to work, with working class students being more likely to do so (Moreau \& Leathwood 2006).

\section{Social Security and Labour Legislation in the Czech Republic}

Czech labour law was harmonized with binding international agreements, the foremost being the incorporation of EU directives into Czech national law (Labour Code Amendment 2000, General Section), which is required for the EU accession process (Vecernik, 2001: 26-27).

Its main goal is harmonizing Czech legislation with that of the European Union, including the social dimension of the common market and the Chart of Basic Social Rights of Employees. The fields of special concern are equal opportunities for men and women, work conditions, employment security and health protection, and employees' representation. From the point of view of work flexibility, the following changes (or lack of them) are the most important (Vecernik, 2001: 27):

- No discrimination is allowed in access to job, to salary, to training and job promotion, and in labour legal relations; for equal work, equal pay.

- Employees have the right to more information about the firm and the firm's situation should be negotiated with them; if trade union organization is not in the firm, employees' councils might be established with support of the employer.

- Contracts for an unlimited period of time are preferred (as previously) but also fixed term contracts were maintained against the pressure to limit them; there are no legal limits in concluding fixed-term contracts and sequencing them except regarding adolescents, school leavers and categories of workers exempted by the collective agreement; ${ }^{6}$ disabled persons are no longer protected. ${ }^{7}$

\footnotetext{
${ }^{4}$ Eurostat Labour Force Survey (2010).

52 Foundation Findings: Youth and work: European Foundation for the Improvement of Living and Working Conditions, 2011.

${ }^{6}$ However, if a person belonging to this category of workers agrees in writing to a fixed-term contract, it can be concluded. The exemption is thus only formal, since the employer can set such consent as a hiring condition
} 
- Fixed-term contracts are not administratively limited; 8 employees working in fixed-term contracts are equal in labour relations and have the same rights as employees in standard contracts (but not the severance pay).

- Compulsory severance pay is limited on two months as before; newly, instead of additional three-months limit which could be concluded in collective agreement no limit is set; the lack of limit for negotiated severance pay concerns also budgetary organizations

- Overtime work was reduced to 150 hours per year, with the possibility to agree on more hours up to the absolute upper limit of 416 hours per year. Work stand-by was reduced to 24 hours per week and 400 hours per year.

- Collective dismissals and related obligations for employers were newly arranged according to EU legislation.

In most countries in the EU, the use of temporary employment contracts is regulated: the maximum duration is limited as well as the number of times the contract can be renewed. ${ }^{9}$ The legal and economic significance of permanent employment status within the employment system will regulate the incentives for employers to use 'precarious' employment forms and the incentives for workers to secure permanent status. One of the major reasons for the use of the various employment forms in the Czech labor market is to avoid the designation of an individual as an employee. Employees may have legal or regulatory rights which impose costs on employers, these range from employment taxes, contributions to social security or health insurance, rights to employment protection, including restrictions on lay-off. The level of these costs will influence the extent to which employers may seek to avoid employee status.

\section{Consequences of Precarious Work}

The growth of precarious work has made educational decisions more precarious too (Kalleberg, 2009:10). The number of young people in employment across the European Union has declined considerably. By mid-2013, the unemployment rate among people aged 24 and under had increased to over $23 \% .{ }^{10} \mathrm{~A}$ large number of workers in this age group are employed on temporary rather than permanent contracts (42\% compared to just $10 \%$ of workers aged $25-64$ ). While temporary or fixed-term contracts can be a stepping stone in the transition from education into work, they can also trap young people in insecure jobs. According to Kalleberg the uncertainty and unpredictability of future work opportunities make it hard for students to plan their education (Ibidem). As mentioned above precarious work creates insecurity, economic inequality and instability. Earnings have become more volatile and unstable. Poverty and low-wage work persist, and the economic security of the middle class continues to decline (Mishel et al. 2007). Precarious work creates insecurity and affects families. This may lead to changes in the structure of communities. Moreover, uncertainty about the future may affect couples' decision making on key things such as the timing of having children, get married, as well as the number of children to have (Coontz 2005; Kalleberg 2009:9).

Students in our survey are engaged especially for administration, teaching, working in manufactures, doing some marketing positions, sales, services and finally telecommunications. The biggest employers are Czech Insurance Group, DHL, Telefónica, Siemens, ŠKODA AUTO (also having a higher education school), T-Mobile, Honeywell, Raiffeisenbank, Coca-Cola Hellenic, Ernst Young. The most frequent type of jobs done by the students is in the area of real estate, services for businesses, educations, other public and personals services and trade. In terms of type of employment the highest number of students work as technical or pedagogical workers, followed by scientific and expert workers followed by managers in services and trade. Students work is subsidized in the sense that student is entitled to, in addition to general tax deduction, also to a special additional student tax deduction. According to the statistics findings our survey shows that most respondents see their work as a reason to interrupt their studies and most of them have interrupted their studies due to work.

Our survey highlights some major issues on precariousness such as:

- Most of public university students prefer temporary working positions - part-time jobs

- Most respondents who hold a part-time job do so because they're undergoing education, and followed by

\footnotetext{
7 In fact, this was asserted by the "disabled lobby" in Parliament, with the intention that disabled persons would not be discriminated against by employers because of such obligation (Vecernik, 2001: 26-27).

${ }^{8}$ MLSA (Ministry of Labour and Social Affairs) asked for the insertion into the Amendment of a statement that, in a fixed-term contract, its reason should be stated, so that the time period of the contract would conform to the reason stated. This was, however, not accepted by Parliament (Vecernik, 2001: 26-27).

9 The report Young people and temporary employment in Europe. Available at http:/www.eurofound.europa.eu/emcc/erm/studies/ tn1304017s/index.htm

10 The report, Young people and temporary employment in Europe. Available at http://www.eurofound.europa.eu/emcc/erm/studies/ tn1304017s/index.htm
} 
those who want to have that type of job.

- Most respondents who have temporary jobs do so because they don't want a permanent job.

It also shows the extent of precarious employment. Such employment not only covers employees with fixed term and temporary contracts, and some categories of self-employed workers, but also workers with low incomes or short working hours. These forms of employment among students are on the increase and seem to become a necessary step when first entering the labour market. Moreover they are frequently associated with poor working conditions. However some respondents said they could not find a permanent job. Most respondents had minor jobs (less than a year or less than 20h/week), but followed closely by those who held regular paid jobs. Most Czech respondents were full time students, followed by part-time students and some visiting. There are two basic types of contracts for students: full time job and jobs out of main job relationship (the employment agreement, agreement on work activity). Then there are specific types like contract of employment, work organized by another agency, self-employment and finally undeclared work. Students on temporary contracts of various durations, be they directly employed or hired through an agency, may benefit from a job in the short term, but live with uncertainty, as to whether their contract will be extended. All employment conditions in our survey are defined and written in the Labour Code (262/2006). There are different time spans, different conditions for each of types. Also the important thing in the labour code is that there is no explanation of the term „student", thus their rights do not take into account specific nature of student work. There are two ways how students are supported in the Czech Republic - general support for all students and support for socially disadvantaged students. Some grants and social support are tied to social situation of a student. From state one can get social benefits for citizens in need - in case their income is less than 30\% (in Prague 35\%) of normative given by the relevant law (Act n. 117/1995 Col. on State Social Support). Other social benefits that students can get are child benefits - a student is entitled to get this type of social benefit till 26 years of age, if without income. One condition is that family's income is lower than 2.4 multiple of subsistence minimum), orphan's annuity (when a student is without income and one or both parents are dead), and social allowance (when a student's income is lower than subsistence minimum). According to the respondents in our survey it is not a problem to find and employ a fresh graduate without experience but it is more profitable to employ a student and thus help him/her gain experience. Full-time students found that working during term-time was associated with poorer degrees being awarded. Furthermore, the longer the hours worked, the greater the risk of a poor degree. Since the need to work was greatest for the students with the fewest material resources, the outcome was "these students worked for a short-term cash benefit and emerged from university with large debts, a history of working in bars and shops, and poorer degree results" (Callender 2008). The findings for the Czech Republic, however, gave different results.

Student Income and Expenditure survey ${ }^{11}$ found that one third of full-time students who had jobs felt that their employment impacted on their studies, with the most common reason being that they spent less time reading and studying. Part-time students were more likely to feel that work was having a damaging effect on their studies, with about half believing that it did (Johnson et al 2009). In our survey majority of the respondents don't belong to any trade union, student union or student association. The most significant educational trade union in the Czech Republic is BohemianMoravian Syndical Association of Persons Employed in Education (BMSA). The BMSA is an association predominantly for employees in education, the retired and unemployed persons who used to work in education. This association of citizens is focused mainly on lobbying on behalf of its members in order to collectively influence employers, public administration bodies and local authorities. In general, the institutions do not offer students any special help in the Czech Republic. But some of study programs and fields offers students some kinds of work, e.g. tutoring - a student doing a guide to a foreign student; teaching in maternal or Czech languages schools; being a member of a research team etc. There is no special support for students who work. If a student is missing on lectures or seminars because of his/her work, there is no tolerance. Only non-attendance because of illness is tolerated. But if a student wants to work in full time job, she/he can choose study programs and fields which offer also so-called distant form that provides them full working time with a few compulsory lectures. This form of study is ideal for those who work and if often chosen by those who apply to study but already work. Such students have only irregular Friday and Saturday lectures. However their study load is not decreased only adapted to their special needs. The diploma obtained through this form of study is equal to a regular attending one and it is not even stressed in the final document confirming the graduation. In connection with education, quality of education can be apprehended from different perspectives. According to one, the quality of education is nothing more than the ability to educated students to be highly-educated labour force, which is committed to permanent studying and self-instruction. In this approach precarious work among students is dealing with the issue of

11 The Student Income and Expenditure Survey (SIES) 2011/1. Available at https:/www.gov.uk/government/uploads/system/uploads/ attachment_data/file/301467/bis-14-723-student-income-expenditure-survey-2011-12.pdf 
social protection which needs to be addressed to make sure young people and others in temporary jobs have adequate access to benefits when their contract ends.

\section{Conclusion}

Precarious forms of work have drawn attention from international and national actors for years and has a deep impact on societies. There is still theoretical vacuum in sociological understanding of the nature of precarious work among students' population. Sociologists have to explain the mechanisms generating 'student precarity' but also to offer public policy solutions.

Most European studies have agreed that as student numbers rise, and state and family financial support becomes more restricted, more students are working, and for longer hours, both during and between terms. It is obvious that precarious work is a phenomenon that exists in the Czech Republic as well as in other countries in Europe. More attention ought to be paid to a special interaction between the role of higher education institutions and students on the labour market.

Generally speaking, the development of precarious work is increasingly a source of concern not only for the growing numbers of those engaged in such employment, but also for institutions providing education service. Precarious jobs among students in generally have left a young generation hard pressed to see a bright future. Increasingly the literature points to a combination of factors, sometimes emphasizing one above another, but rarely asserting that precarious work derives from one consideration only. For some authors (Evans \& Gibb, 2009) precarity involves a mix of forms of contract and job insecurity. They refer to forms of work characterized by atypical employment contracts, by limited or no social benefits or statutory entitlements, by high degrees of job insecurity, low job tenure or low wages (McKay, 2012).

As employment among students continues to grow, there is a role for both trade unions and students' union to address the welfare needs of students. It is obvious that precarious work is a phenomenon that exists in the Czech Republic as well as in other countries in the EU, so therefore more attention ought to be paid to a special interaction between the Czech welfare system and the tertiary education system. Finally, we should encourage the development of qualitative studies on employees concerned by flexible contracts, in order to understand how they feel about them and manage to fit them into their occupational paths, and to relativize the sometimes inadequate assimilation of 'atypical job' and 'precariousness'.

\section{References}

Balogh, G. (2011) Features of 'talent-branding' at the University of Pécs. The paper was written with the support of project 'TÁMOP4.2.2/B-10/1-2010-0029 - SROP-4.2.2./B-10/1-2010-0029

Supporting scientific training of talented youth at the Univerity of Pécs. Available at www.eco.u-szeged.hu/download.php?doclD=25379

Callender, C. (2008), The impact of term-time employment on higher education students' academic attainment and achievement, Journal of Education Policy Vol. 23:4; pp 359-377.

Coontz, Stephanie (2005) Marriage, a History: From Obedience to Intimacy or how Love Conquered Marriage. New York: Viking

Cremers, J (2010) 'Non-standard employment relations or the erosion of workers' rights, Solidar Briefing Paper No. 2, pp 1-11.

Balogh, G. (2011) Features of 'talent-branding' at the University of Pécs. IAPNM Conference, 10th International Congress of the International Association for Nonprofit and Public Sector Marketing, Porto, Portugália, CD.

Hammer, T. (2002) Youth Unemployment, Welfare and Political Participation: a comparative study of six countries. In Changing labour markets, welfare policies and citizenship. The Policy Press.

Hetesi, E. - Braxmair, Zs. (2011): University impact and impress on student growth- a conceptual model of the measuring value added in a higher education institution.

IAPNM Conference, 10th International Congress of the International Association for Nonprofit and Public Sector Marketing, Porto, Portugália, CD.

Evans, J. Gibb, E. (2009) Moving from precarious employment to decent work, ILO - for the Global Union Research Network.

ILO (2012) From precarious work to decent work: outcome document to the workers' symposium on policies and regulations to combat precarious employment / International Labour Office, Bureau for Workers' Activities. - Geneva: ILO, 2012. Avaliable: http://www.ilo.org/wcmsp5/groups/public/---ed_dialogue/---actrav/documents/meetingdocument/wcms_164286.pdf

Janíčko, P. (2013) Precarious Work in the Czech Republic. The 7th Inernational Days of Statistics and Economics, Prague, September 19-21, 2013. 497-508.

Johnson, C., Pollard, E., Hunt, W., Munro, M., Hillage, J., Parfrement, J. \& Low, N. (2009), Student Income and Expenditure Survey 2007/08, English-domiciled Students, DIUS Research Report 09 05, London: Department for Innovation, Universities \& Skills.

Kalleberg, Arne L. (2009) "Precarious Work, Insecure Workers: Employment Relations in Transition." American Sociological Review, Vol. 
74 (February: 1-22).

Kretsos, L. (2010) 'The persistent pandemic of precariousness: young people at work' in J. Tremmel (ed.): A Young Generation Under Pressure?, March, New York: Springer.

Leschke, J. (2012) Has the Economic Crisis Contributed to More Segmentation in Labour Market and Welfare Outcomes? ETUI Working Paper 2012.02.

Martin, G. (2009) A Portrait of the Youth Labor Market in 13 Countries, 1980-2007. In: Monthly Labor Review.

Mishel, Lawrence, Jared Bernstein, and SylviaAllegretto (2007) The State of Working America2006/2007. Ithaca, NY: ILR/Cornell University Press.

Mishel, Lawrence, Jared Bernstein, and Sylvia Allegretto (2007) The State of Working America 2006/2007. Ithaca, NY: ILR/Cornell University Press.

McKay Sonia, Jefferys Steve, Paraksevopoulou Anna and Keles Janoj (2012) Study on Precarious work and social rights. Carried out for the European Commission. (VT/2010/084). Working Lives Research Institute, Faculty of Social Sciences and Humanities, London Metropolitan University. Available: ec.europa.eu/social/BlobServlet?docld=7925\&langld=en

McKay, S., Paraskevopoulou, A. \& Keles, J. (2012) A review of recent literature for the study on precarious work and social rights, London: Working Lives Research Institute for the European Commission.

Moreau, M-P. \& Leathwood, C. (2006) Balancing paid work and studies: working (-class) students in higher education, Studies in Higher Education Vol. 31:1, February 2006, pp. 23-42.

Polónyi I. (2010) Foglalkoztathatóság, túlképzés, Bologna. Educatio, 3, pp. 384-401.

Szolár É. 2009: Az európai felsőoktatás átalakulása és a Bologna-folyamat céljai. Iskolakultúra, 19, 9, pp. 95-119.

Stone, W. (2000) "Social capital, social cohesion and social security, paper presented at the Year 2000 International Research Conference on Social Security, 25--27 Sep., Helsinki. Available at: http:/www.aifs.gov.au/institute/pubs/papers/stone2.html

Teichgraber, M. (2013) EUROSTAT European Union Labour force survey - annual results 2012. Statistics in focus 14/2013. Available at: http://epp.eurostat.ec.europa.eu/statistics explained/index.php/Labour market and labour force statistics\#cite note-0

The European Commission (2013) Working together for Europe's young people - $A$ call to action on youth unemployment (2013). Available at: http://ec.europa.eu/europe2020/pdf/youth_en.pdf

Vecerik, J. (2001) Labour Market Flexibility and Employment Security. Czech Republic, Institute of Sociology. Czech Academy of Sciences. Prague. ILO. Available at: http://www.oit.org/wcmsp5/groups/public/---ed_emp/documents/publication/wcms142349. pdf 